\title{
The development of a strategy for the facilitation of income-generating projects in rural communities: an insider account
}

\author{
Anna-Marie Trollip
}

\begin{abstract}
OPSOMMING
Die grondslae en ontwikkeling van 'n strategie vir die fasilitering van inkomstegenererende kunshandwerkprojekte in landelike gemeenskappe word kortliks uiteengesit. Die uiteensetting berus op gegewens wat verkry is tydens twee opeenvolgende fases van ' $n$ navorsingsprojek in die Noordelike Provinsie van die Republiek van Suid-Afrika. Drie projekte wat sonder, en drie wat onder die leiding van een of meer fasiliteerders gefunksioneer het, is in die eerste fase van die navorsing bestudeer. Faktore wat doeltreffende funksionering inhibeer is geïdentifiseer en die rol en funksie van projekfasiliteerders is ondersoek. 'n Aktiwiteitsmodel vir die fasilitering van inkomstegenererende projekte is op grond van die navorsingsresultate en aan die hand van die prestasiemodel van Blumberg en Pringle (1982; aangepas deur Robbins, 1993) ontwikkel. Gedurende die tweede fase van die navorsing is daar by die aktiwiteite van ' $n$ inkomstegenererings projek in die Winterveldt naby Pretoria ingeskakel. Die eerstehandse insig wat so verkry is, is gebruik om die voorgenoemde aktiwiteitsmodel te verfyn.
\end{abstract}

Daar is tot die gevolgtrekking gekom dat 'n ontwikkelingstrategie voorsiening moet maak vir die ont wikkeling van menslike hulpbronne en dat die konteks waarbinne projekte funksioneer deurentyd in ag geneem moet word. Die doeltreffende funksionering van projekte word deur velerlei sosiokulturele en ander faktore geïnhibeer. Dit is ook noodsaaklik dat daar van owerheidsweë inligtings - en ander hulpstrukture geskep en in stand gehou moet word om mikro-ondernemings te ondersteun om wins gewend te funksioneer.

\section{- Prof AM Trollip}

Department of Consumer Science, University of Pretoria

\section{INTRODUCTION}

As a cultural dress researcher I became sensitive to the plight of women who live in rural areas with little infrastructure. In the course of fieldwork on cultural dress in the northern region of South Africa, I came across several women's groups who were trying to generate income by producing sewing and craft-art products. Few of these projects were operating successfully. The project members seemed to lack product development skills (identification of target markets and marketable products, product design and quality control). These skills were within the range of my knowledge base.

An attempt to assist a group during 1994 failed dismally, mainly because of my inexperience and ignorance as a facilitator. The process and outcomes were planned from my perception of the needs of the target group - a typical example of top-down planning. The group never took ownership of the project. This failure offered major challenges, for instance:

- What is successful community development all about?

- What should the outcomes of an incomegenerating project be? Which goals should be set?

- Which skills should be taught?

- How could the involvement and participation of the members be ensured?

- What should the role of a facilitator be?

Against this background and at the time a study was planned with the overall goal to contribute to developing an approach towards skills training and facilitating income-generating groups who produced craft-arts or sewn products. A study was planned in three phases:

- Identifying and analysing the problems and needs of income-generating groups who worked with and without the assistance of a facilitator

- Joining an existing successful group working under the guidance of a facilitator in order to develop an understanding of group culture and functioning

- Working on an experiential basis with a newly established group, applying the insights gained during the first two phases to test and refine a strategy to promote income-generating community projects.

PHASE 1: DETERMINING THE PROBLEMS AND NEEDS OF INCOME-GENERATING GROUPS 
When the first attempt to assist an income-generating project was considered, the previous failure with such a project was mainly ascribed to the following factors:

- Insufficient insider understanding of the full extent of the problems and needs of groups who were trying to generate income in underdeveloped rural areas

- Not helping the group to acquire the full range of skills to operate optimally

- The inability of the women to help themselves, which was ascribed to insufficient motivation to overcome constraints.

It seemed logical to conduct a needs analysis to understand the nature, scope and context of the problems of income-generating groups. Recent literature (McKillup, 1998:261) confirms that a needs analysis is a decision-aiding tool in programme planning and development in various fields, including that of human services.

The needs analysis has two primary components, namely identification and assessment. Needs identification implies that information is gathered on those in need, their environment, problems confronting them, and solutions to these problems. Needs assessment takes the process one step further. The information is synthesised and options are ordered for the purposes of decisions. As I saw a lack of motivation as a possible obstacle in the way of successfully solving the identified problems, I conducted a literature study on this aspect and used a framework from this field for interpretation of the findings.

The specific aims formulated for the first phase of the study were therefore to:

- identify factors that hamper the successful operation of income-generating groups

- compile and compare the needs profiles of income-generating groups who were working with and without the guidance of a facilitator

- investigate the role and functions of the facilitator.

Two important learning experiences occurred during the planning stages of the first phase of the study:

- The opportunity to attend a short course in participatory rapid appraisal (PRA) methods during 1995 sensitised me to research methods that would facilitate self-reliant development through the participation of community members.

- I went on a study tour just before commencement of the second phase of the study (1997), visiting the north and south of Thailand to observe the functioning of successful home-based microenterprises. These enterprises were living examples of self-reliant development based on the full participation of community members to achieve goals that were set with respect to their needs at the time.

Theoretical framework and appropriate methodological approach for Phase 1
A model adapted by Robbins (1993:230) from Blumberg and Pringle (1982) to relate performance dimensions was used as a general theoretical framework for this part of the study. This model illustrates the relationship between the performance of an individual, his/her abilities and his/her motivation. It acknowledges that opportunities can aid or hinder individual performance. Opportunities include personal and material resources such as training and development, equipment, technology and accommodation. Abilities include knowledge and skills, such as product development, production, quality control and various marketing skills. Motivation is defined by Robbins (1993:205) as " ... the willingness to exert high levels of effort toward goals, conditioned by the effort's ability to satisfy some individual need." According to this viewpoint, a need represents some internal state that makes certain outcomes appear attractive. An unsatisfied need will cause tension that in turn generates search behaviour to attain particular goals, which, if attained, will satisfy the particular need and reduce tension.

Mouton (1996:16-38) aptly states that the manner in which development is perceived dictates the methodology that should be used. Participatory methods such as participatory, learning and action methods (PLA), facilitate the participation of people in their own development. PLA methods gained importance with the paradigm shift towards participatory development during the eighties (Wetmore \& Theron, 1998). They encompass methodologies such as participatory action research (Burkey, 1993), participatory observation (Spradley, 1980; Pelto, 1970), participatory rural appraisal (Chambers, 1997), and the dialogical intervention strategy (Romm, 1996).

Acceptance of the premise that poor people should be allowed to transform their environments progressively by their own praxis is a driving force in the PLA ideology (Rahman, 1991:148-149; Wetmore \& Theron, 1998). It acknowledges that the community members (actors) possess valuable knowledge. It encourages self-development as well as a creative approach to information sharing and learning, and flexible yet structured analysis. The actors participate fully in learning about their needs and opportunities and in formulating the appropriate process to address them (Stadler, 1995). The facilitator plays a catalytic role in this process but should not dominate.

The methods and techniques used in a participatory learning approach are qualitative in nature. This $\mathrm{m}$ plies, as is true of a typical qualitative strategy, that the researcher/facilitator cast off preconceptions and theoretical concerns and approach the research process with an open mind. "The aim is no longer to substantiate but to sensitise, not to explain, but to conscientise and learn, not to plan but to strategize a process based on a continuous cycle of action-reflectionaction" (Wetmore \& Theron, 1998:40).

Dialogue is an important instrument of the participatory methodology to transform concepts into action, 
followed by reflection - a continuous cycle of dialogue, action and reflection. In this dialogical process, the facilitator or researcher's approach should be rooted in empathy and sensitivity. Only then can the e searcher maintain an understanding of the community and its ever-changing needs.

This article does not aim to present a comprehensive overview of specific PLA methods and techniques. The literature on these methods is growing steadily. And as authors in this field so aptly state: "PLA largely involves organised common sense, with a dose of creative ingenuity, borrowing of methods, adapting and inventing, within a specific participatory mode" (Wetmore \& Theron, 1998:43).

\section{Method}

The Northern Province of South Africa was selected as a typical underdeveloped region for a study to identify the needs and problems of income-generating groups who were producing either craft-arts or sewn products. Using snowball sampling as a nonprobability technique, three income-generating groups working without a facilitator and three who were working with a facilitator were included in the sample. None of the groups was aware of the others' existence. Only two groups worked in regions less than $100 \mathrm{~km}$ apart. The groups were identified with the assistance of $n$ formants I had met through cultural dress research.

Various PLA methods were employed to gather the data. The findings were interpreted in accordance with motivational theories. A more comprehensive report on this phase of the study was published in 1997 (Trollip, 1997). A brief summary of the most important findings follows below.

\section{Discussion of the findings of Phase 1}

The findings of Phase 1 underlined the multitude of problems groups have to contend with. They faced problems arising from insufficient capital and transport as well as distance from markets and suppliers, lack of knowledge in the areas of product development, marketing, leadership and management skills. Insufficient knowledge of target markets caused the production of unmarketable products.

An interesting picture emerged from an analysis of the needs as perceived by the members of the two types of income-generating groups that were investigated. A shortage of money was indicated as the most salient overall need. The needs of the groups that operated without a facilitator centred on survival. These group members were concerned about their inadequate skills in the areas of marketing and production, and they indicated a need for a facilitator to assist and train them. The groups who were working with a facilitator indicated needs of a personal nature (spiritual and work satisfaction) as well as needs related to their families (the housing and education of their children) (Trollip, 1997). These groups seemed to have transferred responsibility for their survival to their facilitators.
Both group types also had needs to which they were not sensitive. They did not realise that they lacked knowledge of their target market and its culture. This caused unrealistic expectations about the marketability of their products in terms of aesthetic aspects, quality, pricing and therefore competitiveness. Nor did they experience their lack of managerial skills as a need. Tasks were not allocated according to ability and skill. In those groups who worked with the guidance of a facilitator, the facilitator's knowledge, skills and understanding of the market partly compensated for the lack of skills and understanding of the groups. These groups were relatively successful. However, the groups became very dependent on the insights and decision-making skills of their facilitators. They would therefore still not be able to operate independently if the facilitators were to withdraw. Wetmore and Theron (1998) state that such dependence undermines self-reliance and sustainability - the very aim of development.

The findings of this phase of the study (Trollip, 1997) clearly indicated that groups who worked under the guidance of facilitators were more successful than groups who worked without the assistance of a facilitator. The knowledge of the facilitators about the needs and tastes of the target markets resulted in the production of marketable products. The facilitators also set product goals based on product philosophies, quality standards and delivery dates. They mediated funding and assumed responsibility for the financial management of the projects.

Although it is of major importance to help the groups operate independently, it is unrealistic to expect unsophisticated rural women to understand the cultural and product requirements of a sophisticated market, or even to realise that their own needs were related to an understanding of the target market. They would not be able to function effectively without the assistance of a facilitator - at least during the initial stages of project establishment. On the other hand it is just as important for the facilitator to understand the culture of the group. Without this insight he or she would be unable to sensitise the members to their needs, to strategise the setting of attainable goals, norms and motivation.

The findings of this phase of the study also indicated that the performance and motivation of the groups were severely hampered by insufficient opportunities. Their undeveloped infrastructure caused major problems. The fact that electricity was not available limited the use of production technology. Poor roads and expensive transport hampered the sourcing of raw materials and the transfer of products to markets. Since these factors were extrinsic to the groups, they could do little to improve the situation. Networking among groups and role players in development could provide a measure of relief.

It is therefore clear that intrinsic factors relating to ability and motivation lie within the immediate scope of the groups and their facilitators. Factors relating to opportunities are extrinsic to the groups and can be e- 


\section{A STRATEGY FOR EMPOWERMENT}

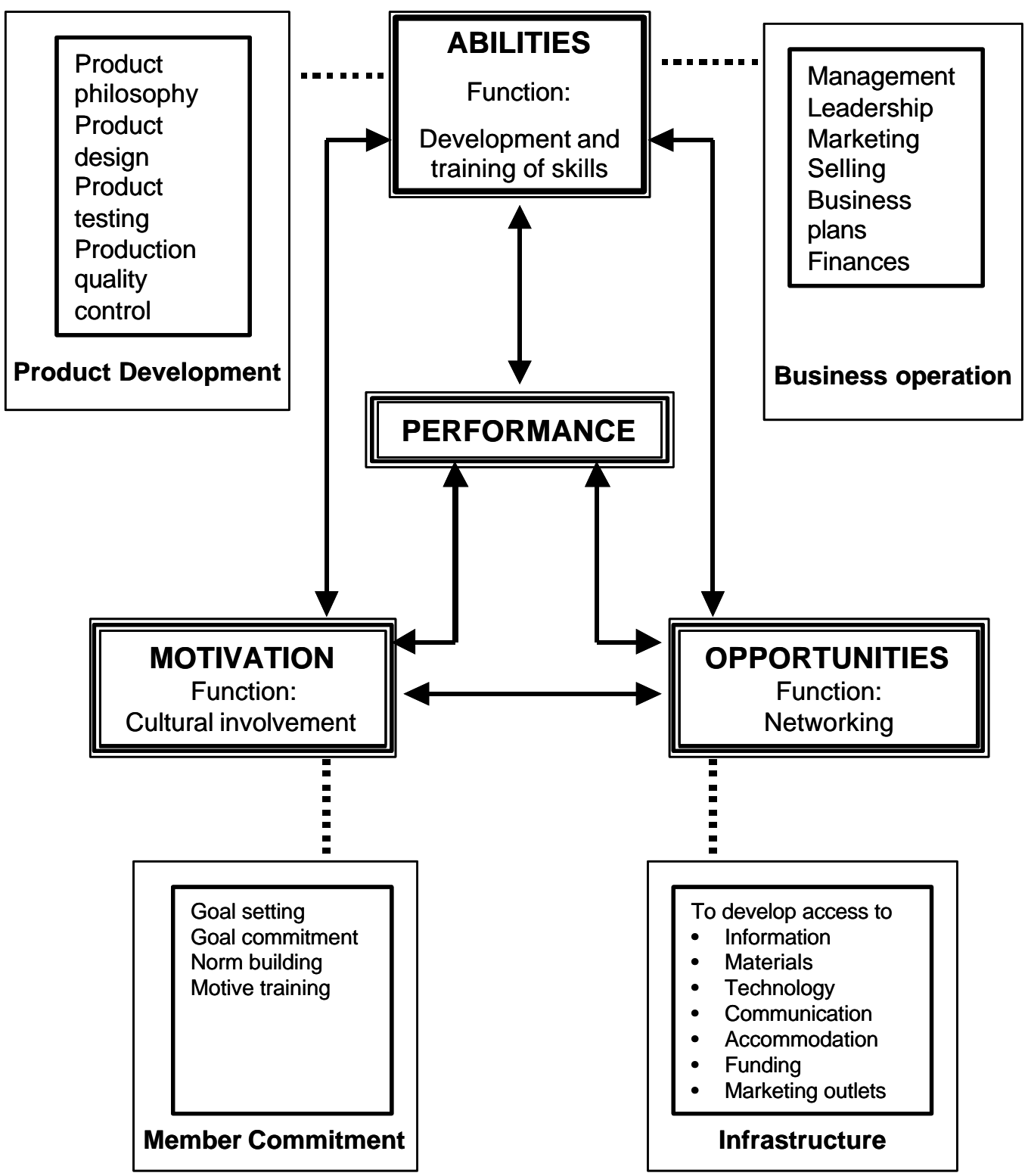

\section{FIGURE 1: $\quad$ ACTIVITY MODEL}

solved to a limited extent only. The provision of infrastructure to support these groups is a function of government. This infrastructure should also include informational services so that groups and facilitators working in isolation could obtain advice on various issues identified in an area.

The results of this phase were communicated to the role players. Further research is recommended $\mathrm{e}$ garding the facilitation of groups who generate income by manufacturing goods. The performance model of Robbins (1993:230) was used to develop an activity model (Figure 1) for this purpose.
The key constructs of the model are equated with areas of involvement. Abilities can be developed by means of needs -based training programmes. Respect for and knowledge of each other's culture would facilitate mutual understanding. Group members should understand the tastes and preferences (aesthetic values based on culture) of their target markets if they are to produce acceptable products. The facilitator should understand the culture of the group, including cultural restraints to which they are subject, before the groups can be helped to formulate attainable goals. Networking is important to develop opportunities such as support structures. See Figure 1 for the activities that should take place. 
PHASE 2: JOINING AN EXISTING SUCCESSFUL GROUP WORKING WITH A FACILITATOR

The findings of the first phase of the study provided some insight into a variety of problems for incomegenerating projects. The first effort to guide such a group sensitised me to the importance of group culture. I also assumed that the groups functioning with a measure of success have developed ways and means to resolve some of the problems they face in underdeveloped areas. I therefore joined an existing group with the aim to gain insider information on group culture and the modus operandi of a successful group.

\section{Method}

The selected target group had at the time been working together for a period of more than five years. This group operated under the auspices of a well-known elite women's organis ation. A Roman Catholic adult training centre in Winterveldt, north of Pretoria, provided accommodation. The group produced embroidered household items such as cushion covers, place mats and tablecloths and had already established itself in the national and international markets. The quality of the embroidery was outstanding. However, the construction of the actual products was poor and lowered the value of the finished product.

The group's products were sold at various craft markets. The researcher met and became friendly with members at one of these markets. Permission to join the group was obtained from the facilitating organisation. It was arranged that the researcher would visit the group weekly, one day per week, for a period of ten weeks to help them improve the quality of their finished products. A fixed involvement period was specified to ensure that the members understood that involvement would not be permanent, and to ensure that the facilitation policy would not be disrupted too much.

The assistance of a black postgraduate student, Mrs Mosima Masekoameng, was enlisted to facilitate entrance into the group and to overcome language problems. She had experience of community development work and her positive attitude and friendly manner assured our speedy acceptance by the members. My role included teaching sewing skills, and Mosima interpreted the instructions to the group members. Discussions with the members were continuous during our visits; we listened to them and observed how they worked.

\section{Discussion of the findings of Phase 2}

Insights gained from this phase of the study reiterated the fact that the overall driving force shared by all the members who had joined the project was the need to generate income. Although this project could be classified as successful, the incomes of most of the members were marginal. However, joining such a project at least provided an opportunity to generate income in a rural area where poverty had such a downward spiralling effect that people could not even afford to move from their homes to find jobs farther away than the immediate vicinity.

I realised that although everybody shared the need for income, the abilities of each member eventually $\mathrm{e}$ sulted in different goals for individual members. The more artistically gifted group members sold more products than the less skilled and less talented persons. Gifted members took part in Arts Council competitions and won prizes consisting of substantial amounts of money. They experienced privileges such as opportunities to travel abroad to man international exhibits and take part in international trade shows. Individual goals therefore ranged from earning income to sustain a meagre existence to self-realisation and status through the production of embroidery with artistic merit.

For this reason the involvement and interest of individual members in the continuation of the project were mostly in line with the compensation they received. However, as is probably common, there were also members who, driven by compassion for fellow members, exerted themselves to ensure continuation of the project. These efforts frequently left them less time for production and their income dropped accordingly.

Nor did the group function without conflict between the members and between the members and their families. Differences in income caused envy. The benefits attached to being successful resulted in severe competition and a power struggle between the leaders that eventually caused the group to split in two. The conflict affected everyone as each leader had her supporters.

In the more traditional households, the economic empowerment of the wives caused conflict between husband and wife. The wife's income represented a threat to the husband as the traditional head and breadwinner of the family. Some of the women suffered severe abuse from their husbands when the proceeds were distributed and they had to hand over their earnings to the husband who then used it to satisfy his personal needs.

Party politics presented an unexpected conflict. As soon as a project showed signs of success, the leaders of political parties would try to take ownership of the project in order to share in the donor funds and to impress voters.

The facilitators of this group tried to avoid taking sides when conflict occurred and to allow the group members to resolve the conflict themselves. They provided moral support to the abused women and tried not to follow a set time schedule for paying out earnings and to do so unobtrusively. Payments were handed out in envelopes without announcing the amounts. Highincome earners in a particular month were warned not to tell the other members what they had earned. The possibility was investigated to negotiate with a bank 
so that group members could open individual bank accounts so that their earnings could be deposited directly into the respective accounts without the hus bands or fellow members knowing about the deposits.

Involvement in this project underlined the importance of fostering the independence of the group from the facilitator. Although the total income of this group was substantial, the group would have had severe problems to survive if the facilitating organisation had withdrawn its involvement. The members were little more than employees. They did not manage their own $\mathfrak{f}$ nances or made decisions about their product lines. Sourcing and buying the raw material as well as marketing the finished product was handled by members of the facilitating organisation. This again illustrated the importance of one widely accepted requirement for successful development, namely self-reliance. It was important to allow and assist the group members to participate in the group's general administration and management, and especially in its financial management.

Quality control is vital to ensuring the marketability of the group's products. This particular project manager exerted a measure of quality control. Criticism of group members' work was not always accepted well and sometimes even caused conflict. As all the products were marketed on an equal basis, the fact that work of poor quality did not sell forced the producer to improve her standard of work to earn an income. However, this alone did not seem to motivate a group member to undo unacceptable finished work. A though they needed the money desperately, the women were reluctant to work on previously finished articles. Their attitude was: Even if it is not good, I may get lucky and somebody will buy it. This fatalistic attitude caused the accumulation of stock that would probably never sell.

Experience on this project not only alerted me to issues that a facilitator should try to avoid or others that could have a negative impact on the operations of a group, but also to ways of ensuring success. The factors that probably contributed most to the relative success of the project were the way in which the project was managed and the product philosophy. One of the members had been appointed as manager. She earned a small salary to compensate her for the time she had to spend on training new members and on administrative duties. She played an important role in the continuation of the project. This person was one of the links with the facilitating organisation. She disciplined the members whose attendance of daily meetings was poor. She asserted a measure of quality control and distributed and controlled fabric and embroidery thread. The project had a product philos ophy and as the group's products were very popular, control was strict to remain within the boundaries of this philosophy. Creativity in design was fostered, but always within certain limits. This resulted in a particular, recognisable character for the group's products, and this distinctive character was put to good use in marketing the products.
The time I spent with this project provided new nsights, some of which caused a measure of discomfort:

- Development caused a change in values and this had negative implications. This aspect was illustrated by the conflicts that occurred in households and among members.

- Members have different personal goals, some related to skills and others to personal circumstances and cultural constraints.

- The willingness and ability of individual members to be involved in the actual running of the project were closely related to the aforementioned abilities and circumstances.

- The importance of the transition from being cependent on a facilitator to being self-reliant was again highlighted.

Issues around the conflicts that occurred emphasised the importance of the facilitator's cultural insight into why conflict occurred and how it should be handled. Wasserman and Kriel (1997:67-69) warn against assuming that communities consist of harmonious interest groups. Malan (1988) discusses the influence of the cosmological factor in development and highlights several causes of conflict.

The community developer should keep in mind that members develop different needs and goals. The goalposts for the project would probably need shifting from time to time. Wasserman and Kriel (1997:29) emphasise in their overview of community development literature that situation analyses should be a recurring activity because development causes perpetual cultural change.

It was again clear that a facilitator/developer played a variety of roles (eg planner, organiser, adminis trator, expert, mediator). It is of vital importance to help group members to take over these functions.

At the time I planned to spend with this group, I hoped to find solutions to some of the problems the groups have to cope with to survive. However, my involvement in this project emphasised the importance of external issues. These may be classified as "opportunities" in the activity model (Trollip, 1997). In this project, where the product is embroidery, there is very little the women can do to raise their income above a certain level. An experienced artisan can produce $\mathrm{x}$ number of articles per week and no more. By improving the quality of her work, however, the work may sell sooner. And value can be added by making bigger articles (and asking higher prices). However, these items sell more slowly.

The factors that can make some contribution to larger profits are frequently beyond a group's control. For example, if raw materials were purchased at wholesale prices from outlets that were closer to the project area, production costs could be reduced. Market expansion could facilitate the sale of more articles. An entirely new structure would however be required to 
facilitate exports. People who are illiterate and operating at marginal levels would hardly be able to cope with such challenges. There do not seem to be any institutional structures on the South African public sector's side to provide assistance to craft projects specifically. Perhaps the necessary extension services are not functioning as they should. If this is the case, the need for networking is emphasised.

Organisations such as the one that facilitated the embroidery project could accomplish much. However, they may be more intent on short-term goals (helping the project's members to earn an income to cover survival needs) and social goals than accomplishing long-term business-oriented goals.

\section{IMPLICATIONS FOR THE FACILITATION OF DE- VELOPMENT PROJECTS}

Firstly, the outcomes of these projects illustrated the principle that participation is both a means to and an end in human development. They underlined the opinion, discussed by Wasserman and Kriel (1997:61) in their overview of community development, that self-reliant participatory development not only encourages people to develop means to survive physically, but fosters the development of selfconfidence, pride, initiative, creativity and responsibility. Successful community development implies human development.

Secondly, the findings of these studies pointed to the importance of the meaning-giving context of a community for the successful operation of a project. Kotze and Kotze (1996) describe this meaning-giving context as an ecology of ideas influenced by past experience, beliefs, values, perceptions and a world view of the assumed structure of reality (culturespecific set of existential assumptions), and ethos as the approved style of life of the particular community. The same authors contend that people's meaning giving context is the only framework within which they can relate to the persons who facilitate development.

This approach is compatible with the humanistic view that people create their own reality by giving things and action meaning. A social reality is formed when these meanings are shared (Berger, 1969:3-13). Social reality continually grows through a process of dialogue, influenced by the values and norms of the community. The unique intellectual abilities of man enable him to perceive and interpret his world. He can reason about it, consider alternatives and make choices according to his perceptions of alternative options. People are therefore able to revise their world in the light of their understanding of alternative positions.

Hölsher and Romm (1989:110) equate development with a dialogical process. Since this process is always influenced by the meaning-giving context of the particular community, it will never be value-free. It follows that if development strategies need to have relevance for a particular community, they need to be planned in conjunction with the people who are to participate in the development process. These strategies should consider the particular structure and context in which the community exists as well as its needs and aspirations.

Against this background, the following two principles should direct the facilitation of projects:

- People should participate in their own development.

- People should set their own goalposts according to their own aspirations, which depend on the context in which they live and their daily reality.

\section{REFERENCES}

BERGER, PL. 1969. The sacred canopy. New York. Anchor

BLUMBERG, M \& PRINGLE, CD. 1982. The missing opportunity in organizational research: some implications for a theory of work performance. Academic Management Revue Oct:565.

BURKEY, S. 1993. People first: a guide to selfreliant participatory rural development. London. Zed.

CHAMBERS, R. 1997. Whose reality counts? Putting the first last. London. ITP.

HöLSHER, F \& ROMM, N. 1989. Development as a process of human consciousness: elements of a humanist view of development. In Coetzee, JK. 1989. Development is for people. Johannesburg. Southern.

KORTEN, DC. 1990. Getting to the 21st century. Boulder, CO. Kumarian.

KOTZE, DA \& KOTZE, PMJ. 1996. What is wrong in development? Focus Forum 4(1):1-8. Pretoria. Human Sciences Research Council.

MALAN, JS. 1988. The cosmological factor in development programmes. South African Journal of Ethnology 11 (2):6166.

McKILLUP, J. 1998. Need analysis: process and techniques. In Brickman, L \& Rog, JB. 1998. Handbook of applied social science research methods. London. Sage.

MOUTON, J. 1996. Theory, metatheory and methodology in development studies. In Coetzee, LK \& Graaff, J (eds).

1996. Reconstruction, development and people. Johannesburg. International Thomson.

PELTO, PJ. 1970. Anthropological research: the structure of inquiry. New York. Harper \& Row.

RAHMAN , MA. 1991. The rhetorical standpoint of PAR, In Fals-Borda, O \& Rahman, MA (eds). 1991. Action and knowledge: breaking the monopoly with participatory action research. New York. Apex.

ROBBINS, SP. 1993. Organizational behavior. Concepts, controversies and applications. 6th ed. Englewood Cliffs, NJ. Prentice Hall.

ROMM, N. 1996. A dialogical intervention strategy for de velopment. In Coetzee, JK \& Graaff, J (eds). 1996. Reconstruction, development and people. Johannesburg. International Thomson

SPRADLEY, JIP. 1980. Participant observation. New York. Holt, Rinehart \& Winston.

STADLER, J. 1995. Development, research and participation: towards a critique of participatory rural appraisal methods. Development Southern Africa 12(6):805-814.

TROLLIP, AM. 1997. Towards developing a model for the empowerment of rural South African women. Journal of Die tetics and Home Economics 25(1):2-10, 18.

WASSERMAN, I \& KRIEL, JD. 1997. Facts and fallacies. Perspectives on community development. Pretoria. Wasserman \& Kriel.

WETMORE, SB \& THERON, F. 1998. Community development and research: participatory learning and action - a development strategy in itself. Development Southern Africa 15(1):29-54. 